\title{
An Account of Teaching Strategies which Promote Student-Initiation
}

\author{
Ahmed Mohammed Saleh Alduais \\ Department of English Language, King Saud University (KSU), Riyadh, Saudi Arabia \\ Email: ibnalduais@yahoo.com
}

Accepted: October 28, 2012 Published: November 24, 2012

Doi:10.5296/jsr.v3i2.2614 URL: http://dx.doi.org/10.5296/jsr.v3i2.2614

\begin{abstract}
It has actually become a habit that I (teacher) am the one who talks a lot inside the classroom and you (student) are the one who talks a little and listens more inside the classroom. Needless to say, everyone's method (strategy) is entirely different from everyone else strategy regarding teaching strategies. Yet, every learner's ability of understanding is also entirely different from another learner's ability of understanding. Thus, we need actually to know: why this paper is promoting for student initiation teaching strategies? What does a strategy of teaching mean? What does student-initiation mean? What are the strategies that can promote for student-initiation? What are the advantages of such an introduced approach (student-initiation)? The paper has been concluded with naming a number of the approaches, which can be used to promote for student-initiation. More importantly, a number of the strategies (both collected and suggested) based on discussion and previous studies have been suggested as strategies promoting for student-initiation.
\end{abstract}

Keywords: Teaching strategies, student initiation strategies, students learning preferences, teacher teaching preferences

\section{Introduction}

Arguably, teachers are talkers and learners are listeners some would say. Or both teachers and learners are talkers and listeners some others would suggest. It has actually become a habit that I (teacher) am the one who talks a lot inside the classroom and you (student) are the one who talks a little and listens more inside the classroom. Needless to say, everyone's method (strategy) is entirely different from everyone else strategy regarding teaching strategies. Yet, every learner's ability of understanding is also entirely different from another learner's ability of understanding. Thus, we need actually to know: why this paper is promoting for student initiation teaching strategies? What does a strategy of teaching mean? What does student-initiation mean? What are the strategies that can promote for student-initiation? What are the advantages of such an introduced approach (student-initiation)? 
Principally, it is argued whether students should be given more time than teachers to talk inside the classroom, or as usual teachers should talk more than their students? Actually, teaching, namely teaching methodology has a long arguable history. Say it another way, many approaches are introduced and everyone is trying in one way or another to justify and promote for his or her suggested approach. In spite of this, the problem now is not which approach is being used for teaching a particular component of language or skill, rather it is about what is going on inside the classroom, namely interaction of all: teacher, student(s), curriculum and knowledge (in the sense of general teaching) and/or language (in the case of languages teaching).

With reference to sociology, a sociologist would consider a person who has a lot of friends and active interaction with the society, community or whatever around him or her as a sociable person. On contrary, a person who hardly has a friend and poor communication with his or her society and community members would be considered by a sociologist as an unsociable person.

Again in the case of psychology, a psychologist would consider a person who is interactive with people around him or her as an open-minded person. Dissimilarly, a person who likes to be alone, to live with his ideas and feelings would be merely considered as a complex, close-minded, and fossilized person (a psychologically ill-person), albeit, s/he is a normal person.

However, when it comes to teaching and by observing any classroom interaction we can decide what kind of students and teacher we do have in such a classroom. That is to say and according to what has been mentioned above whether this or that teacher and those or these students are sociable, open-minded or not on the basis of how much they are interacting with each other inside the classroom. It should be noted here that we mean by interaction how much time is spent by the students for talking and how much time is spent by the teacher for talking. If there is a kind of balance and sharing the whole time together (teacher and his or her students) then we have sociable teacher and students. If the students have talked more than the teacher did, then we have a very sociable teacher and students. Last but not the least, if the teacher has talked more than his or her students did then we have a kind of unsociable teacher but not necessarily unsociable students!

Moreover and if we focus on language teaching, major theories of language acquisition would agree that more communication (interaction) means more language is acquired. For instance, for Piaget (a Swiss psychologist/ epistemologist), Lev Vygotsky (a psychologist) and some others, a language and more importantly second language is acquired effectively through an interactive social interaction. Again, Hatch, Long, Pica and Gas have introduced their theory (interaction hypothesis) claiming that 'conversational interaction is an essential, if not sufficient, condition for second language acquisition', (Lightbown and Spada, 2006: p. 43). 
Logically, none can claim teaching speaking skill for example for a dumb person or reading or listening skill for a deaf person. Similarly, none can claim teaching writing for a person without hands, teaching reading for a blind person unless it is to read for him or her and he or she repeats, or (as it is done for persons with such disorders-prepared syllabuses for such kind of people). Again, even when it comes to people with such disorders their competency in such skills will be very limited even if compared to the learners with very poor knowledge. So the point is that teachers need to make sure that their learners are involved in every skill they are learning. Put another way, the more our students are involved in receptive skills (reading and listening) the more these skills are developed and the more our learners are involved in productive skills, the more these skills are also developed. Of course, the same thing will be applicable to other language components: be it sound system, vocabulary or grammar structures.

Simply, what do you expect from a class of speaking the teacher is the only one who is speaking and his or her students are incomparable with other equipments available in the classroom (tables and chairs)? Or what do you expect from a class of reading when the teacher is reading and asking questions and his or her students are only listeners? Yet, what do you expect from a class of writing the teacher is writing on the board and the students are only copying what he or she is writing on the board?

It is a truth that must be known to every and each teacher that our students must not be tables and chairs-like; they must be allowed to talk when they are being taught speaking and listening and they must be allowed to practice and to be as active as possible inside the classroom in order to be independent learners.

Hence, involving our students in many discussions inside the classroom and turning the class to a simple debate/ discussion be it a language class or any other field of study will no doubt make it certain that a teacher can decide whether his or her students have [digested] the introduced lesson or not. Needless to say, this kind of discussion should be lead orderly and systematically without making the class just like a noisy shopping centre.

\section{Teaching Strategies}

Generally speaking, a teaching strategy is any method which is used by any teacher inside the classroom to introduce, interact and communicate with his or her student/pupils, etc. on the other hand, students initiation would mean generally the ability of both teacher and his followed methodology (strategy) inside the classroom to motivate, encourage, and stimulate the students so that they participate as much as possible inside and during the classroom.

Flanders (1970) assumes that a teaching strategy which promote for students initiation is the one which can result to making an independent student, a students who behaves and interacts inside the classroom interactively and effectively. He adds a good teacher is the one who uses 
his or her authority to make the students initiate the process of interaction inside the classroom and initiate many related ideas in relation to the issues discussed in the classroom.

Flanders (1970:p. 335) suggests that a teacher's response strategy for clarifying ambiguous issues inside the classroom and 'diagnosing learning difficulties' can be very helpful and effective strategies for promoting student-initiation. Furthermore, he adds, more effective strategies can be based on the teacher's 'inquiry' about the needs, situations and things can be motivated for his or her learners to be independent and self-directed learners.

Joyce mentions in Guthrie's (2002: p. 1180) that a teaching strategy which he calls a 'model' is 'a particular approach to instruction'. It suggest again that any method or types of behaviours used by a teacher inside the classroom to interact with his or her students.

Richards, Schmidt, Kendrick and Kim (2002: p. 89) introduced what they called 'communication strategy' to refer to the a learner's attempts, say (behaviours) to interact and communicate with his or her teacher, classmates or people outside using either 'mime, gesture' or any utterances that can express his or her ideas regardless of their accuracy and correctness, but they indicate in one way or another the learner's willingness and intention to communicate using the foreign language he or she is learning.

Richards, Schmidt, Kendrick and Kim (2002: p. 420) also introduced Paolo's Friere strategy of 'problems posing' which can to a great extent help a teacher to encourage student-initiation. It does so because the topic (problem) is chosen according to the different and various interests of the students which mean in one way or another they are going to try lead by their curiousity to manage saying something.

Scaffolding theory introduced by Burner and some others can be used also as a strategy which promotes for student-initiation. Basically, this theory emphasises on the importance of 'collaborative discourse in language learning, (Richards, Schmidt, Kendrick and Kim, 2002: p. 466). Moreover, scaffolding as a teaching strategy can be used to promote student-initiation through engaging learners in 'collaborative problem-solving' activities, (ibid).

It should be noted here that the term (student-initiation) by itself is a strategy which is actually used by learners of either a foreign or second language to express their 'conscious and unconscious processes of learning and using language' (Richards, Schmidt, Kendrick and Kim, 2002: p. 515). Yet our issue in this article is to search for strategies used or can be used by teachers to promote and increase the use of such approach (strategy) by students so that the language they are learning becomes more understood and their abilities of learning become more accurate and independent.

Moreover, it should be noted that it has been a habit that a teacher initiates, the students response, and then the teacher evaluates or provides feedback, namely called 'classroom 
discourse' or 'classroom language', (Richards, Schmidt, Kendrick and Kim, 2002: pp. 73-4). For that matter, it seems important that we need to keep the track on but with more focus on that students themselves should be encouraged and welcomed to initiate their own ideas in relation to what is going on in the classroom. Again, other issues happen inside the classroom [must] be taken into consideration: namely classroom ethos or climate 'the effective dimensions of a classroom such as atmosphere and feelings of the classroom that can promote or detract from effective classroom teaching and learning', classroom interaction '... types of social relationships which occur within classroom', and classroom management (students' behaviours, setting and grouping and aids and methods used by the teacher to make the class as effective and useful as possible), (Richards, Schmidt, Kendrick and Kim, 2002: p. 74).

Bender (2003-2004: p.38) ascertains that a teacher can use the strategy of asking the students to write about their interests, because anyone likes to write about his or herself. S/he adds that reading aloud strategy can be also used to evaluate students' oral ability. Hence, what is important here is that the former strategy can be adapted: the students are first asked to write about themselves and then they will be asked to speak rather than to write so that they can communicate in the classroom orally and initiate interaction since the talk is about their own experiences. Needless to say, this can be done only when asking for example the learners to apply any task, say, teaching tense and aspect or any other subject, say history, so students can interact and initiate ideas when a teacher ask them to add and participate in any related information or to add the history of their countries, etc.

Furthermore, a good teacher teaches a lesson the way his or her students want it to be taught, because learners are different from one another regarding their learning abilities, (Bender, 2003, 2004: p. 39). Put another way, a teacher should vary and use different strategies when teaching (some students want to participate more and they must not be disappointed, some other are still shy in the first classes and they must encouraged and treated intelligently and carefully and some others do not even like to take part during the class and they only want to listen and those also must be treated in a way that shows them the positive effect(s) of participation on the development of learning.

Bender (2003, 2004: p. 49)) emphasised on the importance of taking notes and observation during the classroom by the teacher and providing answers for them to make sure that the students are benefiting from what they are learning. These notes will include providing answers for questions such as 'were the majority of my students involved in the lesson? During what parts of the lesson did students participate the most? The least?, and what activities engaged the greatest number of students? The least number?'.

It seems true that teaching is not just lecturing; it is to interact with your learners in whatever level so that the process of learning becomes more effective. Bender (2003, 2004: p. 60) claims that 'the teacher with the quietest classroom and most complaint students is not necessarily an effective teacher'. S/he adds that 'classrooms where good teaching is taking place will be noisy and seemingly disorganised at times'. 
In discussing pedagogy, Greer (2002: p. 4) mentions that unless a particular activity, strategy or technique is involved and the student responses/ interacts with it in the process of teaching, or it cannot be considered as pedagogy 'pedagogy comes fully into play only when the student is responding'. He adds, 'it includes the teacher activities that occasion the student's response and teacher responses to the student's effort'.

More importantly, teaching is not a fully job of the teacher if talking about a successful and effective teaching it is rather what Greer (2002: p. 5) describes as a 'dynamic interaction among four components: (a) the student, (b) the teacher, (c) the curriculum (or what is being taught), and (d) the learner repertoire (how to use and when to use it)'.

Hannell (2008) introduced 1001 teaching strategies and activities for effective teaching and communication among teacher, students, curriculum and repertoire. Hannell stresses on the importance of understanding first how language is learned (language processing) how do our students think, what do they need to do and how a teacher can make them interact and be involved in everything they are learning?

Amazingly, some would believe that giving the students chances to initiate their own ideas and inquires during the classroom will waste the time of the class, lecture or whatever; a thing which I personally think is wrongly followed. In other words, I would just go with what Jane Vella mentions in McAuliffe's and Eriksen's (2002: p. 1) that 'you probably teach well without recognizing that, often, the more teaching, the less learning. Our job in adult education is not to cover a set of course materials, but to engage adults in effective and significant learning'.

Giving the students a chance in the classroom to interact with each other and to discuss what they have learned is also a good strategy which can encourage them to share their ideas with the teacher and to be self- directed learners. Mcloed, Fisher and Hoover (2003) indicate the importance of the time distribution of the time of each class by the teacher. Say it differently, how much time has been given to the students to communicate and prove that they have learned something in a particular class which again proves the importance of function strategies which promote for student-initiation?

In their case study about the impact of in-service education and training on classroom interaction in primary and secondary schools in Kenya between the teacher and the students in Ollington's book (2008: pp. 101-131), Sifuna and Sawamura argue that teaching is not only an interaction between teacher and students or and pupils, rather it is and it should be interchangeably and exchangeably done. According to them it should be like that 'teacher-pupil interaction, pupil-teacher interaction and pupil-pupil interaction', (ibid, p. 120).

Enyedy, Wischnia and Franke in Ollington (2008: pp. 133- 53) discuss the advantages of leading contrastive and consensus conversation in the classroom discourse. Analytically, they 
show such types of conversation can result to independent and self-directed learners. Above all, they ensure the idea of increasing the chance of learning when the students interact and communicate whatever they learn and hear from their teachers. Again, it suggests that student-initiation should be encouraged and more strategies which promote for such an approach should be encouraged.

Morge (2005: p. 935) has 'recorded, transcribed and analysed' sixteen sessions taught by eight teachers in junior schools and high schools investigating the hidden beliefs of teacher-pupil interaction. She introduced three approaches of interaction analysis: (a) a teacher talks and a student responses, focus is on what the teacher says, proponents of this approach include: Cameron 2002, Newton and Newton 2000, etc, (b) 'noting different verbal behaviour in pupils and teachers, focus on what the teacher and the pupil say, proponents of this approach include: Flanders 1970, Postic 1977, etc., and (c) 'studies both the structures of teacher-pupil interaction and the elements of which it is composed, focus on dynamics of teacher-pupil interaction', proponents of this approach include: Franceschelli and Weil-Barais 1997, and Lemke1990, etc, (ibid: p. 937). Thus it is concluded that strategies for evaluating students' answers, responses and participations should vary and take into consideration that we need to build independent students who can share and produce their own ideas in terms of science teaching.

Myhill (2006) argued in favour of talking as a tool of learning. Put it differently, for Myhill a classroom must not be controlled completely by curriculum and teacher's talk which affect negatively the process of interaction between teacher and his or her students. The study is concluded with that [talk, talk and talk] and of course it means here the learners must talk and participate as much as possible. One of the strategies introduced here is asking open question which allow students to say their own ideas and predict as much answers as possible without reservations.

Broadhead, Cuckle and Hodgson (1999) introduced three dimensions: (a) school-wide dimension, (b) teacher-action, and (c) pupil-learning dimension which have to be merged together for the purpose of the development of pupil-learning. It actually suggests that teaching is not only a matter of teachers and curricula, students or and pupils are always there as the basic goal of teaching is pupils or and students. For that matter and since students-initiation approach has been proved as useful and effective, it should be encouraged by adopting as many strategies as possible which make use of such an approach and allow the students to interact during and inside the classroom.

Adalsteinsdottir (2004) has examined the behaviours and practices of 20 small and large school teachers, the teachers have been categorised into three categories: empathetic teachers, non-empathetic teachers and uncommitted teachers according to the behaviours and practices they do inside the classroom. It has been concluded that the majority of the teachers lack the ideas of understanding themselves (behaviours and practices) which negatively affects on the process of learning especially when the interaction between students and their teacher is lost 
or not valid during classes.

Smith, Hardman and Higgins (2006) investigated the advantages of interactive whit boards (IWBs) during classes; they attempted to find some differences between students studying conventionally and students being taught with the use of (IWBs) in terms of interaction, participation and more importantly initiation during the classes. Researchers have come up with that 'initiation move was more likely to be in the form of an open question within IWB lessons- but this positive finding was somewhat diminished by the briefer answers from pupils within IWB lessons', (p. 454).

The known and world widely used approach of leading the classroom (initiation, response and evaluation) (IRE) has been encouraged by some educators and researchers and criticised by some others. For instance, consider, (Nystrand, 1997) in Hall and Walsh (2002: p. 189) who states that 'students in classroom whose interaction was limited primarily to the IRE script were less able to recall and understand the topical content than were students who were involved in more topically-related, participatory discussions'. One can ascertain that student-initiation approach is more effective than teacher-initiation approach as it allows students to recall more information and knowledge from what they have learned and at the same time, are more independent and self-confident.

(Wells 1993) in Hall and Walsh (2002: p. 190) introduced dialogic interaction as a strategy for more students interaction and initiation in the classroom. In fact, this can be done along with the IRE patterns (initiation (teacher), response (students) and evaluation (short evaluations)), in the IRE script, the teacher only evaluates whatever has been said by students as in response to his or her posed questions. In other words, it is just a matter of proving or disproving what the students say on the basis of the knowledge of the teacher and the provided answer [utterance] by the student. For instance, consider the following example:

Teacher: who can tell me the main idea of this passage?

Student: it is about a girl who lost her purse and never found it again.

Teacher: this is exactly right!

Consequently, the conversation between this teacher and not only the student who has provided the answer, but also the other students who may be were preparing themselves to say something different, similar; more or less than has been said by that student, has been broken-down. However, in this approach, (dialogic interaction), the major aim of it is to keep the track on; to turn the class into a discussion where in every students is saying something without any restrictions or reservations. Thus, this can be achieved only when the teacher's goals and strategies are flexible and take into consideration the advantages of the idea that the more the students talk the more they learn, be it language classes or other fields' classes. Again, consider the following example for this strategy:

Teacher: who can tell me the main idea of this passage? 
Student: it is about a girl who lost her purse and never found it again.

Teacher: this is right, but who can elaborate more about this idea or think that it is not the right one?

Student: ....

As a result, the conversation will go on and on, some of the students will feel comfortable to agree partially, other disagree even if they partially wrong, but at the end and after a long conversation, the teacher will provide his or her final answer to the argued topic.

Flutter (2007) maintains that the student's voice is very important for the teacher development in different issues: teacher's behaviours, actions and all kinds of actions followed inside the classroom.

Rojas-Drummond and Mercer (2003) promoted in their study for the use of peer discussion and spoken interaction inside the classroom in order to achieve what has been claimed by the authors from the point of view of Vygotsky's ideas that there is always a relationship and influence between 'intermental (social aspect of language) and 'intramental' (individual-psychological aspect of language), (p. 100).

Kyriacou and Issitt (2007: p. 61) argued against that the majority of the teachers of mathematics stick to IRF (initiation, response, and feedback) patterns. It is suggested that such an approach (strategy) restricts the students' participations and initiations. For that matter, some strategies are proposed: (a) 'going beyond IRF' (by asking open questions), (b) 'focusing attention on mathematics rather than performativity', (by encouraging mathematical thinking instead of providing correct answers), (c) 'working collaboratively with pupils' (by sing dialogues and interacting with each other), (d) 'transformative listening' ('genuine' responds to the students' contributions), (e) 'scaffolding' (encouragement), (f) 'enhancing pupils' self-knowledge concerning how to make us of teacher-pupil dialogue as a learning experience' (theoretical knowledge about interaction), (g) 'encouraging high quality pupil dialogue' (by responding to the students in a motivated manner), and (h) 'inclusive teaching' (taking into consideration all provided contribution regardless of their correctness or wrongness, (p.62-3).

Brett (2001) conducted an eight weeks project attempting to find some communication strategies for beginner learners of a foreign language (German) and to investigate the possibility of teaching them to the students. Communication strategies named as 'closers' (remarks to compete talk) and 'openers' (remarks to initiate talk)', (p. 57) have been introduced and mentioned as effective ones for beginners. It has been concluded that 'the most effective strategies would therefore appear to be those that allow beginners to initiate and maintain conversation', (p. 54).

Generally, teaching strategies have been defined as:

Teaching strategies are approaches to teaching students. For instance, breaking information down into digestible chunks, allowing more 
time for taking a test, providing a scribe, checking in to make sure the student understand the directions, teaching hands-on and/or with manipulatives. Anything that helps a student grasp the material and/or level the playing field when it comes to a child with an educational disability.

Kerdpon (2009) conducted a study investigating the perceptions of the dental faculty students regarding student-faculty interaction and its effect on the academic development and achievement of the students. It has been concluded that the majority of the students feel more comfortable and gain more knowledge and academic achievement according to the degree of interaction inside the classroom and outside the classroom also. The researcher has recommended for promoting strategies which encourage more interaction among the students and their teachers, be it school level or university level.

Wang (2008) conducted a study analysing instructional strategies and teacher-student interaction in the classrooms of Chinese immersion school. There were four strategies of teaching or types of teachers to be compared: (Laoshi A, Laoshi B, Laoshi C, and Laoshi D), each one of them has followed different and various strategies during the period of teaching the students. For instance and as conclusions for this study: for A Laoshi the teacher-student interaction 'aimed to foster the teacher student relationship than to promote language production', B Laoshi 'focused more on content comprehension and offered more questions on comprehension check', C Laoshi 'interacted with her students to offer guidance, to invite the students' opinions, to stimulate their thinking', and for D Laoshi 'content comprehension and functional language use were equally important, the students were being 'invited to express their comments' and are being 'induced' to produce new knowledge, (pp. 153-4).

Hachiya (2006) made an attempt to 'to develop an appropriate teaching schema for elementary school art activities', (p. 172). According to the conclusions of this study 'respecting students' ideas', giving them the sense that their ideas are not neglected are wrong or right, and encouraging the students to produce their own ideas and use their imagination and think during the classes are the most effective strategies that can help producing independent and self-directed students, (pp. 168-9).

Lloy (2004) conducted a study investigating the effects of teaching methodology for students of science, teaching methodology including teacher-pupil classroom interaction and other activities performed inside the classroom. The study was built on theories and concepts derived from Vygotsky's ideas on learning, and constructivists' view(s) about learning. For Vygotsky, for example, the most effective learning is achieved through social interaction (teacher-pupil interaction, pupil-society interaction, etc), (p 23). Again, for the constructivists 'learning is seen as an inquiry guided by question and ideas', (p. 27). Thus, it is concluded that teachers need to manage as many strategies as they could which allow student to initiate and interact inside the classroom so that we get students with sharpened minds and high 
cognitive abilities.

Arguably, some researchers and educators would argue that the more aids we use during the class the less interaction, specifically (students initiation) we get (more details look at: McCabe, 1997). This actually happens when students will spend their time trying to understand what is going on especially for ones without basic skills in using computers. On contrary, some other would argue that using different and more aids during the class will be reflected positively especially when the students' curiousity is provoked which results to student-initiation interaction instead of teacher-initiation interaction. For instance, Cawyer (1994) reports in his/her study the positive attitudes and perceptions of the faculty students of social science compared to the negative attitudes and perceptions of the faculty students of life science towards their professors' behaviours and strategies in the classrooms. Unlike the social life professors, the social science professors make use of more questions and strategies which allow their students to initiate and participate during the classes.

\section{Conclusion}

In this paper, the researcher has accounted briefly for strategies which promote for student-initiation. It has been stated that teaching is not a purely role of the teacher, it is rather among: teacher, student, curriculum and the learner repertoire. For that matter, a class whose only and even dominating talker is the teacher is unsociable class and lacks any kind of strategy which promote for student-initiation. Therefore, teaching strategies which promote for student-initiation have many advantages which include producing: self-directed, self-confident, self-independent and more knowledgeable learners. From among the most effective approaches of teaching which can promote for student-initiation are: the communicative approach and individual teaching approach. Above all, a number of the strategies which promote for student-initiation learning and teaching have been introduced. These strategies can be mentioned briefly in the following points:

1. Motivating, encouraging and stimulating students to participate in the class room by using different aids and strategies

2. Teacher's response strategy for clarifying ambiguous ideas and issues

3. Communicative strategy: the teacher make his or her best efforts to make the students speak and communicate without disappointing them with terms of 'correctness' and 'wrongness'

4. Problems-posing, especially ones that touches the interests of our learners and provoke their curiousity to not only participate but initiate talking

5. Scaffolding theory (strategy), working collaboratively (team-work), learners are engaged in collaborative working and problem-solving activities

6. Respecting and encouraging students' ideas

7. Asking the students to write about themselves, their interests, adventures, if it is English or language classes, or about their own countries, districts, if it is history or 


\section{Macrothink}

Journal of Sociological Research

ISSN 1948-5468

2012, Vol. 3, No. 2

geography classes, or about their own opinion for other classes. After that the students are being ask to talk about what they have written

8. Collecting data about our learners to see what things and strategies can encourage them to initiate

9. Giving our learners a chance to talk to and with each other, so that they can then initiate talking

10. Leading contrastive and consensus conversations and discussion inside the classroom

11. Talk, talk, talk strategy

12. Dialogic interaction strategy

13. Open-ended questions strategy

14. Taking into consideration that the class is a society or community like which means we need to make all present things participate

\section{Acknowledgement}

The author would to greatly thank Dr. Kebbe (the previously professor of General Linguistics and Phonetics at King Saud University, Riyadh, Saudi Arabia), for his valuable comments on the paper.

\section{References}

ADALSTEINSDOTTIR, K. (2004). Teachers' Behaviour and Practices in the Classroom. Scandinavian Joumal of Educational Research , 48 (1), pp. 95-114, Avilable at: http://search.epnet.com, retrieved at April, 08, 2010.

Bender, Y. (2003,2004). The New Teacher's Handbook: Practical Strategies \& Techniques for Success in the Classroom From Kindergarten through High School . Nomad Press.

Broadhead, P., Cuckle, P. \& Hodgson, J. (1999). Promoting Pupil Learning within a School-development Framework. Research papers in Education , 14 (3), pp. 275-294, Avilable at: http://search.epnet.com, retrieved at April, 08, 2010.

Cawyer, Carol Stringer (1994). A cross-disciplinary assessment of teacher communication behaviors in the college classroom. Ph.D. dissertation, The University of Oklahoma, United States -- Oklahoma. Retrieved April 7, 2010, from Dissertations \& Theses: Full Text.(Publication No. AAT 9422775).

Flutter, J. (2007). Teacher development and pupil voice. The Curriculum Journal, 18 (3), pp. 343 - 354, Avilable at: http://www.musefirst.com/ksu/, retrieved at April, 08, 2010.

Greer, R. D. (2002). Designing Teaching Strategies: An Applied Behavior Analysis Systems Approach . Amsterdam, Boston, London, New York, Oxford, Paris, San Diego, San Francisco, Singapore, Sydney, Tokyo,: Academic Press: An imprint of Elsevier Science.

Hachiya, Masayuki (2006). Beyond 'wonderful': Authentic interaction in the art classroom. Ph.D. dissertation, University of Toronto (Canada), Canada. Retrieved April 7, 2010, from Dissertations \& Theses: Full Text.(Publication No. AAT NR21818).

Hall, J. K. \& Walsh, M. (2002). Teacher-Student Interaction and Language Learning. Annual Review of Applied Linguistics , 22, pp. 186-203 , Avilable at: http://www.musefirst.com/ksu/, 
retrieved at April, 08, 2010.

Hannell, G. (2008). Success with Inclusion: 1001 teaching strategies and activities that really work. UK, Canada: Routledge.

Kerdpon, D.. Student perceptions of student-faculty interactions and academic achievement in undergraduate dental students at Prince of Songkla University. Ed.D. dissertation, Oklahoma State University, United States -- Oklahoma. Retrieved April 7, 2010, from Dissertations \& Theses: Full Text.(Publication No. AAT 3372175).

Lloy, Ella (2004). Young females in science. M.A. dissertation, Mount Saint Vincent University (Canada), Canada. Retrieved April 7, 2010, from Dissertations \& Theses: Full Text.(Publication No. AAT MR06996).

McAuliffe, G. \& Eriksen, K. (2002). Teaching Strategies for Constructivist and Developmental Counselor Education. London: Bergin \& Garvey Westport, Connecticut • London.

McCabe, Margaret Foley (1997). Online classrooms: Case studies of computer conferencing in higher education. Ed.D. dissertation, Columbia University Teachers College, United States -- New York. Retrieved April 7, 2010, from Dissertations \& Theses: Full Text.(Publication No. AAT 9734078).

McLeod, J., Fisher, J. and Hoover, G. (2003). The Key Elements of Classroom Management: Managing Time and Space, Student Behavior, and Instructional Strategies. Alexandria, Virginia: Association for Supervision and Curriculum Development Alexandria,Virginia USA.

Morge, L. (2005). Teacher-pupil interaction: A study of hidden beliefs in conclusion phases. International Journal of Science Education , 27, (8), pp. 935-956, Avilable at: http://search.epnet.com, retrieved at April, 08, 2010.

Myhill, D. (2006). Talk, talk, talk: teaching and learning in whole class discourse. Research Papers in Education , 21 (1), pp. 19-41, Avilable at: http://search.epnet.com, retrieved at April, 08, 2010.

Ollington, G. F. (2008). Teachers and Teaching Strategies: Inovations and Problem Solving . New York : Nova Science Publishers, Inc.

Rojas-Drummond, S. \& Mercer, N. (2003). Scaffolding the development of effective collaboration and learning. International Journal of Educational Research , 39, pp. 99-111, Avilable at: http://www.musefirst.com/ksu/, retrieved at April, 08, 2010.

Smith, F., Hardman, F. \& Higgins, S. (2006). The impact of interactive whiteboards on teacher-pupil interaction in the National Literacy and Numeracy Strategies. British Educational Research Journal , 32 (3), pp. 443-457, Avilable at: http://www.musefirst.com/ksu/, retrieved at April, 08, 2010.

Wang, T.. Instructional strategies and teacher-student interaction in the classrooms of a Chinese immersion school. Ed.D. dissertation, University of San Francisco, United States -California. Retrieved April 7, 2010, from Dissertations \& Theses: Full Text.(Publication No. AAT 3317684). 